\title{
The price of sexual services in nightclubs and massage parlors of San José, Costa Rica: biological and anthropological interpretations
}

\author{
Julián Monge-Nájera and Karla Vega Corrales \\ Laboratorio de Ecología Urbana, Vicerrectoría de Investigación, Universidad Estatal a Distancia, 2050 San José, Costa Rica; \\ julianmonge@gmail.com, kantr.vega@gmail.com
}

Received 1-VII-2011 Corrected 3-VIII-2011 Accepted 24-VIII-2011

\begin{abstract}
Humans and other primates exchange sex for resources. In the case of humans, this exchange includes sexual work. There are few previous studies on sex work in San José, Costa Rica that include data on how much is paid for sexual services. We studied the price of female sex work, and how the profits are distributed among all parties, in nightclubs and massage parlors, by obtaining data from interviews with workers and owners, and from telephone calls, from 1994 through 2010. Prices ranged from US\$6 for a lap dance to US\$300 for intercourse and when inflation is taken into account, they have not increased much in the last ten years. The prices per hour can reach 125 times the minimal wage per hour of work in the country. In comparison with independent sex work done in the streets, parlor and club women benefit from the associated infrastructure, access to clients, and safety, and they receive $40-50 \%$ of the fee paid by men for their direct services (dances, sexual activity), so there is no indication of exploitation on either side. Nightclubs have around $30 \%$ of profit after expenses are deduced. Sexual services are relatively expensive but men pay them because they are biologically and socially oriented towards wanting these services.
\end{abstract}

\section{KEY WORDS}

Sociobiology, evolutionary psychology, "prostitution", women in economy, Central America.

\section{RESUMEN}

Los humanos y otros primates intercambian sexo por recursos. En el caso de los humanos, este intercambio incluye el trabajo sexual. Existen pocos estudios sobre los precios del trabajo sexual en Costa Rica. Estudiamos el precio del trabajo sexual femenino en clubes nocturnos y salas de masaje mediante entrevistas a trabajadoras y dueños, y Ilamadas telefónicas, entre 1994 y 2010. Los precios van desde US\$6 para un baile erótico a US\$300 para el coito y tomando en cuenta la inflación, no han aumentado mucho en los últimos diez años. Los precios por hora puede llegar a 125 veces el salario mínimo por hora vigente en el país. En comparación con el trabajo sexual independiente hecho en las calles, las mujeres de clubes y salas se benefician de la infraestructura asociada, el acceso a los clientes, y la seguridad que ofrecen estos sitios, y reciben el $40-50 \%$ de la cuota pagada por los clientes por servicios directos (bailes, actividad sexual), por lo que no hay indicios de explotación de una u otra parte. La ganancia neta de los clubes es de un $30 \%$. Estos servicios sexuales son relativamente caros, pero los hombres les pagan porque están biológicamente y socialmente predispuestos a querer a estos servicios.

\section{PALABRAS CLAVE}

Sociobiología, psicología evolutiva, "prostitución", mujeres en la economía, América Central.
In Homo sapiens, the behavioral evidence indicates that women in all but the most restrictive societies engage sometimes in extramarital sexual unions. In the USA, the rate is 20 to $50 \%$ for married women (Greiling \& Buss 2000). However, this phenomenon is not limited to humans, females of other species also perform sexual acts in exchange for resources with males that are not their longterm partners (Alcock 2009).
In the case of married women, the benefit from sexual intercourse with men other than their husbands results from becoming impregnated by a genetically superior man (Better Genes Hypothesis), by using sexual intercourse to get rid of a husband (Mate Expulsion Hypothesis), by acquiring a better husband (Mate Switching $\mathrm{Hy}$ pothesis) or as a means of finding a higher-quality mate in case their current partners someday need replacement (Greiling \& Buss 2000, Schmitt \& Buss 2001). 
Additionally, a woman may use short-term mating to deter future affairs after finding that her husband had a relationship with another woman (Preemptive Revenge Hypothesis), to increase her skills (Honing Mating Skills Hypothesis) and to elevate her self-esteem and later make better mating decisions (Self-Esteem Hypothesis) (Greiling \& Buss 2000).

Some of the hypotheses mentioned here are not mutually exclusive, and in summary, the works summarized by Greiling \& Buss (2000) and by Alcock (2009) indicate that women can receive several advantages from sexual activity with a variety of men, including resource accrual, better mates and genes, and improved self-esteem. These factors can apply both to women who have "lovers" and to women who practice sexual work (Buss 2007), a particular case of this relationship that occurs when a woman exchanges sex for an economical retribution (we will avoid the old derogatory term "prostitution" in most of this article). By doing sex work, women can gain access to some men with many resources or to many men with some resources, thus accumulating larger amounts of resources than they could obtain through other means (Resource Accrual Hypothesis; Greiling \& Buss 2000).

In contrast with biology, social sciences focus on how cultures perceive sex work. Historical records indicate that in the temple of Mylitta (Iraq), all women were required to do sex work at least once in life, as part of a religious service that provided funds for the temple (Murphy 1998). A similar view survived until Roman times and still exists in some areas of India, but the rise of the Judeo-Christian and the Islamic patriarchate changed the view in most of the Western Hemisphere with an ideology that rejects sexual practices outside marriage (Murphy 1998). Thus, Judeo-Christian and Islamic societies repress many aspects of human sexuality, including sex work, and define how women and men can see sexuality, with strong gender stereotypes (Murphy 1998, Ortiz et al. 1998).

Under patriarchate, woman is seen as part of the natural goods that man has "the right to posses" and the sexuality of woman is controlled accordingly (Ortiz et al. 1998); woman is the "weak sex" that leads to the "loss of virtue" in man; her "honor"lies in her ability to control her own sexuality, while a man's honor is based in controlling the sexuality of "his women" (Murphy 1998, Ortiz et al. 1998). Even though acceptance of sex outside marriage has changed significantly over the last 50 years in some societies, sex work is often seen negatively (Murphy 1998, Ortiz et al. 1998).

Today, Costa Rican society is the result of the imposition of the Judeo-Christian Spanish culture on the original inhabitants, including a double moral that condemns sex work but sometimes forces women into by keeping them economically vulnerable (Ortiz et al. 1998, Reskin \& Maroto 2011). For example, sex work was allowed in $19^{\text {th }}$ Century Costa Rica, as long as it was not too conspicuous, but in the $20^{\text {th }}$ Century the view changed when sex workers were seen as vectors of disease: a threat to public health (Ortiz et al. 1998). Legislators, social workers, psychologists, politicians and reporters alike deny these women their condition of workers, and as a result, they are particularly vulnerable to many disadvantages and prosecution from authorities and the general Costa Rican public (Zamora et al. 1996, Ortiz et al 1998), just as has long been the case almost everywhere (Murphy 1998). Sex workers, male or female, lack the benefits of social security and labor laws because they are not part of the official economy (Rojas et al. 2009).

The older labels of "temptress" and "source of corruption" have been replaced in recent years with updated labels based on the belief that sex is an intrinsically bad activity that is done with the "dirty" part of the body. The media still associate sex workers with "AIDS" and "foreigners", ask the police what they are doing to deal with "the problem" (despite the fact that sex work is legal in Costa Rica), and report an omnipresence of "sexual exploitation" and "child prostitution" even when no such things are involved (Monge-Nájera et al. 2009). Furthermore, sex workers also have to work cooking, cleaning and raising children in their homes, and this double occupation causes them to feel stressed, exhausted and guilty for not doing enough (Zamora et al. 1996, Herrera 2000).

There are few previous studies on sex work that include data on how much is paid and earned for sexual services in Costa Rica. Reports from the late $20^{\text {th }}$ Century mention payments of up to US\$100 per service (Ortiz 1994) and monthly earnings of US\$50 to US\$480 per woman (Cedeño 1994). More recent data show that women who do sex work have incomes that are far superior to those they would have as cleaning ladies, receptionists, cheap laborers in the "maquila" sector or other jobs befitting their educational level (Monge-Nájera et al. 2009, Ramírez et al. 2009, Rojas et al. 2009). A recent study argues convincingly that sex work enables some Costa Rican women not only to subsist, but also to give themselves and their families a relatively high standard of living (Rivers-Moore, 2010).

This report adds new information from several perspectives: how the prices have changed with time (previous studies dealt only with the prices in their own periods); the amounts earned by nightclubs based on internal accounting data, and additional information on how the profits are distributed. 


\section{METHODOLOGY}

Nightclub data were obtained from an open interview with a person who had internal access to accounting records from two San José nightclubs from 1994 through 2001, and interviews with the owners of two nightclubs. The accounting interview took place in March 2001, the interviews with the owners in 2007 and 2011. Access to such data was only possible because of the rapport established with the interviewed people after several years of fieldwork. Field observations in clubs were made by both authors.

Massage parlor data were obtained by calling the parlors that advertised themselves in the classified ads sections of two daily Costa Rican newspapers, La Nación and Diario Extra, in September and October 2002 and again in November 2010. JMN visited five parlors in 2002 and five in 2010 to corroborate the information obtained by telephone.

Amounts are presented in US dollars according to the exchange rate with Costa Rican currency (508 colones per dollar) as to May $9^{\text {th }} 2011$.

Ethics: we interviewed our informers with respect for their condition was workers or owners, our data do not include information from which individuals can be identified, and the information published in this report can serve as a scientific basis to justify a more honest and equalitarian treatment of sex workers.

\section{RESULTS}

\section{Price of services in nightclubs}

In 2001 clients paid US\$8 to enter a nightclub; others had higher rates but these included two drinks. In 2011 the entrance cost US\$10 and included a lap dance. This basic payment allowed the client to watch the dances, other services were charged additionally. Usually, the services were as follows and the client remains fully dressed except in the intercourse option (all prices in list: year 2001 and then the $2011 \mathrm{fee}$ ):

- Table dance: the woman makes a short "strip-tease" (dance in which she slowly removes all her clothes) near the client table so that he can see her at short range, usually no physical contact is allowed; US\$6 and US\$9.

- Lap dance: the woman dances on the clients lap, rubbing herself against his pubic area and he is allowed to touch her breasts; US\$12 and US\$9. In some places she removes her top for this dance.

- Private dance: the woman dances nude in a private room and the man is allowed to touch her breasts and other body parts (sometimes she will perform oral sex for an additional amount); US\$20 and US\$15.

- Intercourse: full sexual intercourse. Price US\$100 to US\$300 the hour depending on the place; room with jacuzzi: additional US\$75 per hour. In 2001 there was also a "take out" option in which the client was allowed to leave in the company of the woman after paying US\$100 to US\$200 to the club; payment for the rest of the services was defined by the woman but normally was in the hundreds of dollars for a whole weekend. In 2011 the price per hour (including a bottle of champagne) was US\$200 for the house and US\$100 for the woman.

Note: our results are for upper scale nightclubs. Some low-level bars in the poor zone of the city also advertise themselves as "nightclubs". In 2001, clients paid US\$9 per hour including sexual intercourse and room in these bars. The women earned around US\$1000 per month because even though their fees were lower, they had intercourse with several clients on a single night.

\section{Price of services in massage parlors}

Parlors offered a combined service of massage and sexual services that ranged from provoking an ejaculation with the woman's hand to full intercourse with one or several women. Rates normally are given for half or full hours. In 2002 the mean hourly price was US\$15 (in 2010 it was US\$33). From 2002 to 2010 the half-hour cost increased by $27 \%$ and the hour by $12 \%$ (Fig. 1 ).

\section{Distribution of profits}

According to the interview data, the monthly sales for San José nightclubs were high in 1994 (US\$50 000), fell

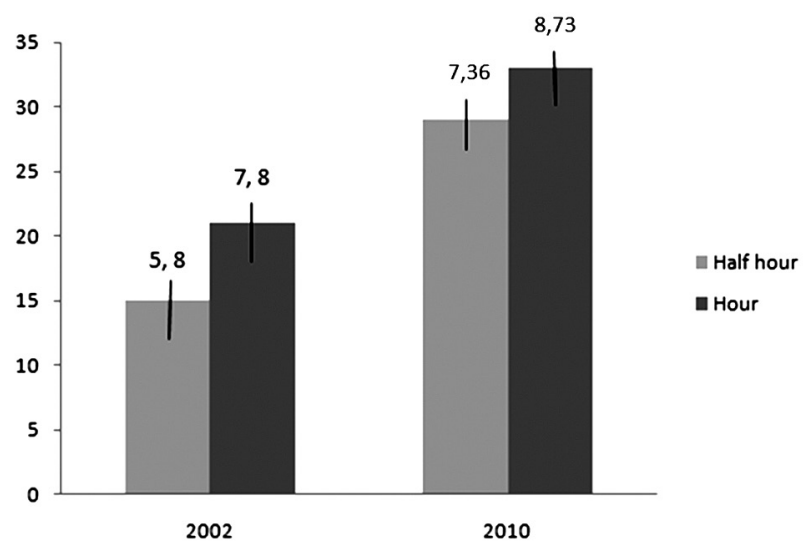

FIG. 1. Mean cost of sexual services in massage parlors, 2002 and 2010 (in US\$). Bars: standard deviations. 
in 2001 (US\$10 000) and by 2007 they were increasing (US\$14 000). Throughout this period, the net profit was around $30 \%$.

In 2001 women from upper scale nightclubs were required to do two dances per night and earned US\$5.9 per dance. They also received US\$1.4 for each simple drink bought by their customers. For the other services (dances, intercourse) the standard proportion of income taken by the women was $40-50 \%$, adding to a monthly total of about US\$2 000. In 2011 the proportion received by the woman for her sexual service was still nearly $50 \%$ of what the client paid.

In massage parlors, $50 \%$ of the fee paid by clients was used by the woman to pay for the use of the facilities; she kept the rest. We could not obtain data on gross and net income for owners of massage parlors.

\section{DISCUSSION}

The amounts spent by individual men in Costa Rican nightclubs and parlors are comparatively high, considering that the prices can range from US\$9 to more than US\$200 per hour, while the minimal wage in the country is US\$2,4 per hour (Costa Rica, Ministerio de Trabajo y Seguridad Social, official salary, downloaded August 1, 2011: http://www.mtss.go.cr/salarios-minimos.html. The prices per hour of sexual services can reach 125 times the minimal wage per hour of work in the country.

Anthropology has proposed several explanations for the use of resources in human societies, including a show of status, and in the case of nightclub and massage parlor clients, their economic status allows them access to physically attractive women. In the case of parlors, men can perform sexual activities that for any reason they will not do with their long term partners, such as having sex with two women at the same time (Rojas et al. 2009), an increasingly popular service that might reflect both a frequent male fantasy and a reaction to commercial sex videos. In the parlors, men can also receive an erotic prelude to sex in the form of oil massages performed in a low light room where scent veils are burned (Murphy 1998, Rojas et al. 2009).

Like practically any other contemporary human society, Costa Rican society stigmatizes sexual work and mainly punishes the women who practice it (while clients receive a less harsh treatment), but at the same time, this society promotes sexual work by maintaining the financial pressure that leads women to it (Ramírez et al. 2009, Rojas et al. 2009).

The relatively high prices of sexual services may reflect not only the supply and demand principle (a very small proportion of the Costa Rican female population sells sexual services) but also the social cost that this work has for women (Rojas \& Scott 1994). The American cliché of the "pimp" that exploits women is absent in Costa Rica, probably because sexual work is legal in this Central American nation. In the USA, where female sex workers practice illegally, they are more easily victimized by policemen, clients, "pimps" and other parties (Murphy 1998).

If we turn from the anthropological interpretation of social pressure to the biological interpretation, the biologically centered Sexual Strategies Theory (Schmitt et al. 2001) is also consistent with our results. Nightclubs and massage parlous benefit from the natural behavior of man towards attractive women and short term mating. Like other mammals, individual humans present a large variation in the resources they can accumulate. Women care greatly for their offspring and sex work allows some of them to obtain a high ratio of resources per hour of work (Greiling \& Buss 2000, Buss 2007).

In turn, nightclub and parlor owners can benefit from men's willingness to spend in sexual services, although they can be subjected to social harassment from neighbors and the police.

Is there exploitation of women in this business? There is exploitation when one party receives a disproportionate part of the earnings. In nightclubs, women receive 40-50\% of the fee paid by men for their direct services (dances, sexual activity), while in turn the nightclub has a $30 \%$ profit after expenses are deduced. The total amount received by the club is much larger that the amount received by the women who work in it, but we ignore if this is different from the total proportion received by workers versus owners of any other business organizations such as religious groups, supermarkets, private schools and any other business organizations. Like workers anywhere, the women do not pay for infrastructure, staff salaries, insurance, taxes, electricity, water, maintenance and other costs (these are covered by the owners of the nightclub or parlor). Just as the owners benefit from the work of their staff, the women benefit from the infrastructure, services, access to clients, safety and social backup network from other workers that they have when they rent rooms in a parlor or work in a nightclub (Monge-Nájera 2009). Women who work independently do not have these benefits, but have more control over when, where and how they do their work.

Our results agree with the finding that sex work allows women to consider themselves good mothers who spend time with their children and provide them a good standard of living that they could not obtain in other forms 
of work, and this helps them to counteract the effects of social stigmatization (Rivers-Moore 2010).

Finally, we were surprised to find that, in contrast with the prices in parlors (which increased slightly), the prices of most nightclub services had not increased significantly in the last decade and were, in some cases, even lower than ten years ago. Possible reasons include:

1. An ideological change: society is more permissive of these businesses now and the reduced danger of repression brings the prices down.

2. The proportion of foreign clients is lower now because of the economic crisis in the USA, and thus the prices are set by the Costa Rican clientele, which can only pay lower prices.

3. The demand for this kind of services is lower in 20102011, bringing the prices down or at least keeping them steady. Possible reasons for a reduced demand is that clients are finding other sources of sexual satisfaction or that that the number of nightclubs is higher now than a decade ago.

4. The 2010-2011 prices were affected by the crisis of the American economy which stopped the trend for the colones/dollars exchange to change frequently in favor of the dollar.

Future studies could address the hypotheses presented above and study similar businesses outside downtown San José.

\section{ACKNOWLEDGMENTS}

We thank the people who trusted us with delicate information, as well as Katya Calderón for her administrative support and Megan Rivers-More and Rosberly Rojas Campos for comments on earlier drafts. Any remaining errors are of course ours.

\section{REFERENCES}

Alcock, J. 2009. Animal Behavior: An Evolutionary Approach. Sinauer, Sunderland, Massachusetts, USA.

Buss, D.M. 1994. The evolution of desire. Basic Books, New York, USA.

Buss, D.M. 2007. The Evolution of Human Mating. Acta Psychologica Sinica 39: 502-512.

Cedeño, M. 1994. Prostitución femenina y Derechos Humanos en Costa Rica. Tesis de Licenciatura en Derecho, Universidad de Costa Rica.
Cruz, A. \& L. Queralt. 2000. Subjetividad femenina. Un análisis de género con cinco mujeres jóvenes dedicadas al modelaje. Tesis de Licenciatura en Psicología, Universidad de Costa Rica.

Greiling, H. \& D.M. Buss. 2000. Women's Sexual Strategies: The hidden dimension of extra pair mating. Personality and Individual Differences 28: 929-963.

Herrera, M. 2000. Detrás del telón... Entre lo imaginario y lo real: estudio cualitativo sobre mujeres en prostitución. Tesis de Licenciatura en Trabajo Social, Universidad de Costa Rica.

Monge-Nájera, J., R. Rojas Campos, R. Morales Bonilla \& I. Ramírez. 2009. Trabajo sexual femenino en la ciudad de San José, Costa Rica: un enfoque sociobiológico al iniciarse el siglo XXI. Cuadernos de Investigación UNED 1: 27-31.

Murphy, E. 1998. Historia de los grandes burdeles del mundo. Plaza, Madrid.

Ortiz, M. 1994. Un análisis psicosocial realizado con 7 clientes y 32 prostitutas del sector central de San José. Tesis de Licenciatura en Psicología, Universidad de Costa Rica.

Ortiz, M., A. Zamora, A. Rodríguez, L. Chacón \& A.L. Gutiérrez. 1998. Soy una mujer de ambiente: Las mujeres en prostitución y la prevención del VIH/Sida. Editorial de la Universidad de Costa Rica, San José, Costa Rica.

Rojas, A. \& M. Scott. 1994. Relatos de vida y representación del dinero en cinco mujeres prostitutas del sector Central de San José. Tesis de Licenciatura en Psicología, Universidad de Costa Rica.

Ramírez Sánchez, I., J. Monge-Nájera, R. Rojas Campos \& R. Morales Bonilla. 2009. La escolaridad en trabajadoras sexuales de la ciudad de San José, Costa Rica, al iniciarse el siglo XXI. Cuadernos de Investigación UNED 1: 33-42.

Reskin, B.F. \& M.L. Maroto. 2011. What trends? Whose choices? Gender and Society 25: 81-87.

Rivers-Moore, M. 2010. But the kids are okay: motherhood, consumption and sex work in neo-liberal Latin America. The British Journal of Sociology 61: 716-736.

Rojas Campos, R., J. Monge-Nájera, I. Ramírez Sánchez \& R. Morales Bonilla. 2009. El mercado del trabajo sexual femenino en la ciudad de San José, Costa Rica. Cuadernos de Investigación UNED 1: 13-25.

Schmitt, D.P. \& D.M. Buss. 2001. Human mate poaching: Tactics and temptations for infiltrating existing relationships. Journal of Personality and Social Psychology 80: 894-917.

Smith, R.L. 1984. Human sperm competition, p. 601-659. In R.L. Smith. Sperm competition and the evolution of mating systems. Academic, New York, USA.

Zamora, A., E. Quirós \& M. Fernández. 1996. Voy paso a paso: empoderamiento de las mujeres, negociación sexual y condón femenino. Ministerio de Salud, Organización Mundial de la Salud and Universidad de Costa Rica, San José, Costa Rica.

\section{Article edited by Vanessa Nielsen-Muñoz}


